Int. J. Electrochem. Sci., 15 (2020) $7545-7558$

International Journal of

ELECTROCHEMICAL

SCIENCE

www.electrochemsci.org

\title{
Effects of Homoacetogenic Bacteria on the Corrosion Behaviour and Cathodic Protection of AISI 4135 Steel
}

Xiangju Liu ${ }^{1,2,3,4}$, Yanliang Huang ${ }^{1,3,4, *}$, Jianzheng Li $^{5,6}$, Dan Yang ${ }^{1,2,4}$, Yong $X u^{1,2,4}$, Qichao Zhang ${ }^{1,2,3,4}$, Dongzhu $\mathrm{Lu}^{1,3,4}$

${ }^{1}$ CAS Key Laboratory of Marine Environmental Corrosion and Bio-fouling, Institute of Oceanology, Chinese Academy of Sciences, Qingdao 266071, P. R. China

${ }^{2}$ University of Chinese Academy of Science, Beijing 100049, P. R. China

${ }^{3}$ Open Studio for Marine Corrosion and Protection, Pilot National Laboratory for Marine Science and Technology, Qingdao 266237, P. R. China

${ }^{4}$ Center for Ocean Mega-Science, Chinese Academy of Sciences, 7 Nanhai Road, Qingdao, 266071, P. R. China

${ }^{5}$ School of Municipal and Environment Engineering, Harbin Institute of Technology, Harbin 150090, P. R. China

${ }^{6}$ State Key Laboratory of Urban Water Resource and Environment, Harbin Institute of Technology, Harbin 150090, P. R. China

*E-mail: hyl@qdio.ac.cn

doi: $10.20964 / 2020.08 .71$

Received: 7 December 2019 / Accepted: 16 January 2020 / Published: 10 July 2020

The corrosion behaviour of high-strength low-alloy AISI 4135 steel was studied in the presence of homoacetogenic bacteria (Blautia coccoides GA-1), which catalyse the formation of acetate from $\mathrm{H}_{2}$ plus $\mathrm{CO}_{2}$ in their energy metabolism. In addition, the effects of cathodic protection were studied. The chronoamperometry curves showed a negative current density. The minimum current density was approximately $-1.5 \mu \mathrm{A} \cdot \mathrm{cm}^{-2}$. The results revealed that the strain GA-1 could consume 'cathodic hydrogen' and promote the cathodic reaction of AISI 4135 steel, but the hydrogen consumption of strain GA-1 was not the main reason leading to the increase in the corrosion current density.

Keywords: High-strength low-alloy steel, Biocorrosion, Homoacetogenic, Cathodic protection

\section{$\underline{\text { FULL TEXT }}$}

(C) 2020 The Authors. Published by ESG (www.electrochemsci.org). This article is an open access article distributed under the terms and conditions of the Creative Commons Attribution license (http://creativecommons.org/licenses/by/4.0/). 